Techniques \& Culture

\title{
Les fondeurs de socs à araire et de marmites
}

\section{Micheline Centlivres-Demont}

\section{(2) OpenEdition}

\section{Journals}

Édition électronique

URL : https://journals.openedition.org/tc/889

DOl : $10.4000 /$ tc. 889

ISSN : 1952-420X

\section{Éditeur}

Éditions de l'EHESS

\section{Édition imprimée}

Date de publication : 1 février 1987

ISSN : 0248-6016

\section{Référence électronique}

Micheline Centlivres-Demont, "Les fondeurs de socs à araire et de marmites », Techniques \& Culture [En ligne], 8| 1987, mis en ligne le 23 janvier 2006, consulté le 29 septembre 2022. URL : http:// journals.openedition.org/tc/889; DOI : https://doi.org/10.4000/tc.889

Ce document a été généré automatiquement le 29 septembre 2022

Tous droits réservés 


\section{Les fondeurs de socs à araire et de marmites}

Micheline Centlivres-Demont 